årsak til en rekke sykdommer. Tanken er at medlemmer av en familie - søsken, tvillinger, foreldre og barn - har mye til felles både genetisk og når det gjelder miljøfaktorer. Informasjon om denne avhengigheten av familiestrukturen kan brukes til å avdekke årsaker til sykdom på en langt mer kraftfull måte enn i tidligere epidemiologiske observasjonsstudier.

Tvillingstudier har lang tradisjon i medisinsk forskning. De er blitt brukt for å avdekke arvelighet for ulike sykdommer. Én svakhet ved slike studier er at tvillinger ikke alltid likner på resten av befolkningen og at deres erfaringer derfor har dårligere generaliserbarhet. I Family matters utvides perspektivet til å utnytte søskeninformasjon - fordi vanlige søskenpar kan ha større nytteverdi enn tvillinger for en del forskningsspørsmål, fordi datasett med slik informasjon kan være lettere tilgjengelig og fordi studier av søsken har større generaliserbarhet. Dessuten omhandles generasjonsstudier, hvor sammenlikninger mellom far-barn og mor-barn kan være en pekepinn når det gjelder hvilken betydning faktorer i svangerskapet kan ha på senere sykdom.

Forfatterne tar utgangspunkt i tvillingstudier og løfter perspektivet til mer enn et spørsmål om arv eller miljø. De diskuterer med eksempler hvordan familiebaserte studier til en viss grad kan brukes til å skille ut genetiske effekter, miljøeffekter og tidspunktet for disse gjennom ulike deler av livsløpet. Familiemedlemmer deler genetisk informasjon, men de deler også sosiale og fysiske miljøfaktorer i visse deler av livet. $\AA ̊$ utnytte tidspunktet for denne likheten kan være av stor verdi i studier av kroniske sykdommer.

Dette er forlagets nyeste tilskudd til serien om livsløpsepidemiologi. En rekke sentrale forskere tar for seg - ut fra ulike innfallsvinkler - statistiske metoder inklusive dataprogrammer, det teoretiske grunnlaget, praktisk anvendelse og kommer med eksempler som illustrerer nytten og bruken av slike studier. At det er aktive forskere innen feltet som selv skriver, gir stoffet et solid preg og tyngde. Temaet berøres ut fra flere faglige perspektiver, nyansert og grundig. Størst nytte av Family matters vil antakelig aktive forskere som selv planlegger liknende studier ha. Men den henvender seg også til klinikere og helseplanleggere som ønsker bedre forståelse av nytten av familiebaserte studier om årsak til sykdom når randomiserte forsøk ikke lar seg gjennomføre. Ikke minst kan den være av interesse for alle dem som undrer seg over hva familieanamnese generelt gir av informasjon. Anbefales.

\section{Øyvind Næss}

Seksjon for arbeids- og trygdemedisin

Universitetet i Oslo

\section{Grunnleggende godt}

Pedersen JI, Hjartåker A, Andersen SA. Grunnleggende ernæringslære

456 s, tab, ill. Oslo: Gyldendal Akademisk, 2009. Pris NOK 575

ISBN 978-82-05-39522-0

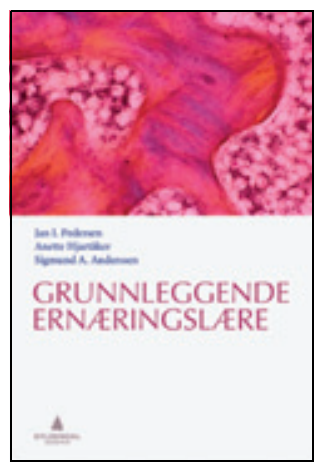

Landsforeningen for kosthold og helse ga ut sin første lærebok i ernæring i 1971. Det kom flere reviderte utgaver, den femte og siste i 2001. Foreningen ble nedlagt i 2005 og Gyldendal Akademisk overtok rettighe-

tene til utgivelsen. Nå foreligger det en ny og mer omarbeidet versjon.

Omtrent halvparten av sidene er brukt på de ulike næringsstoffene. Det gir godt med rom til andre temaer - og det er mye spennende å ta av innen ernæringsfaget. Introduksjonskapitlet om kostdata går inn i metoder og begreper som er spesielle for innsamling av informasjon om kostholdet, viktig for vurdering av kostholdsopplysning både til grupper og enkeltpersoner. Kapitlet om kostholdet i Norge er kortfattet og viktig bakgrunnskunnskap for helsepersonell. Dessverre er flere av tallene etter hvert omtrent ti år gamle, da de bygger på bl.a. Spedkost, Småkost og Ungkost fra 1999-2000 og Norkost fra 1993-94. Forfatterne kan neppe bebreides dette, men det hadde vært flott med noen nye tall i en ny lærebok. Kapitlet om norsk ernæringspolitikk er godt oppdatert og inneholder en konkretisering av målene for handlingsplanen for bedre kosthold i befolkningen, som gjelder for perioden 2007-11.

Utseendemessig fremstår Grunnleggende ernceringsloere som litt kjedelig. Det er mest tabeller og kun noen få illustrasjoner i farger. Når det gjelder illustrasjoner, har fagbøker i ernæring mye å lære av de mange innbydende kokebøkene på markedet. Noen av tabellene ser ut som de er skannet inn og forstørret, og teksten er til dels uskarp. Kapittelinndeling av type 13.1.2 gir et unødvendig kjedelig inntrykk, det er få andre norske lærebøker enn ernæringsbøkene der det blir brukt slik inndeling. Det gjør også at den meget detaljerte innholdsfortegnelsen er på hele ti sider.

Dette er en lærebok som, som tittelen sier, omhandler det grunnleggende i ernæringsfaget. Den har mye å vinne på å være 150 sider kortere enn sin konkurrent. Informasjonen som gis om de ulike næringsstoffene er tilstrekkelig, og forfatterne unngår å gå for dypt inn i patologien. Det er et pluss, ettersom dette nødvendigvis må leses andre steder. Ernæringsfaget utvikles stadig, og det er flott at det finnes to store norske lærebøker på markedet. Grunnleggende ernceringslcere passer godt for studenter innen helsefagene, men siden kostholdet er av stor betydning på de fleste felter, kan en oppfrisking av kunnskapen definitivt komme godt med for flere og gi inspirasjon til å lese mer om det som er viktig i egen arbeidshverdag.

\section{Astrid L. Nylenna}

Kommunelege 2, Ski kommune

\section{Viktig rapport om narkotika}

Europeisk overvåkningssenter for narkotika og narkotikamisbruk

\section{Narkotikasituasjonen i Europa}

Årsrapport 2009. 99 s, tab, ill. Luxembourg: Kontoret for De europeiske fellesskaps offisielle publikasjoner, 2009. Pris gratis ISBN 978-929168401-4

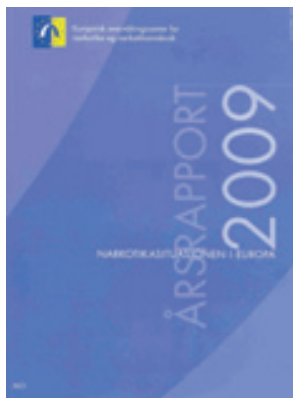

Det europeiske overvåkningssenteret for narkotika og narkotikamisbruk utgir årlig en rapport over situasjonen i Europa. 2009-rapporten er den 15. i rekken. Senterets målsetting er å bidra med kunnskap og informasjon som utgangspunkt for narkotikapolitiske tiltak. Organisasjonen er finansiert av EU og lokalisert i Lisboa. Informasjon fra medlemslandene oppgis å være viktigste bidrag, i tillegg til eget arbeid.

Rapporten består av åtte kapitler. De to første handler om lovgivning og politikk, deretter er det ett kapittel dedikert til hver av de viktigste kategorier stoffer etter utbredelse: cannabis; amfetamin, ecstacy og hallusinogene stoffer; kokain og crack; opioider og injeksjonsbruk. Det hele avsluttes med to kapitler kalt Narkotikarelaterte infeksjonssykdommer og dødsfall og Nye narkotiske stoffer og trender.

15-årsjubileet for rapporten ble markert med en konferanse som viste at Europa «har utviklet seg til å bli et enestående laboratorium for å studere og øke forståelsen av narkotikabruk og narkotikarelaterte tiltak» (s. 5). Dette gir håp om at kunnskapsbasert forskning kan legge premissene for narkotikapolitikken - i stedet for nærsynte betraktninger om rusmidlers farmakologiske og avhengighetsskapende virkninger, som så altfor lett fører til forbud og dermed inntektsmuligheter for organisert kriminalitet. Ifølge en studie finansiert av EU-kommisjonen, presentert på FNs narkotikakommisjons sesjon i Wien i 2009, har håndheving 